\title{
Katja Mahnič
}

\section{Spomin: med individualnim in kolektivnim, med tradicijo in zgodovino}

Zdi se, da je v zadnjih letih ideja kolektivnega spomina postala osrednji pojem humanističnih in družboslovnih razprav. Čeprav lahko razmahu zanimanja za to idejo sledimo v 80. leta prejšnjega stoletja, je bilo za njeno izoblikovanje pomembno delo, ki sta ga sociolog Maurice Halbwachs in umetnostni zgodovinar Aby Warburg opravila slabega pol stoletja prej. Kot poudarja Jan Assmann, je bila skupna točka njunih sicer neodvisnih in različnih teorij zavrnitev predhodnih poskusov, da bi kolektivni spomin razložili kot podedovani oziroma "rasni« spomin. S tem sta raziskovanje kolektivnega spomina iz biološkega premestila v kulturni okvir (Assmann, J., 1995, 125). Zato ne preseneča, da je imela ta premestitev dolgoročne posledice zlasti na dveh raziskovalnih področjih, v zgodovinopisju, še posebej v okviru kulturne zgodovine, in antropologiji. Vendar pa, kot opozarja David Berliner, razmah spominskih študij v okviru obeh ni imel istih vzrokov. Če se je v okviru kulturne zgodovine spomin kot osrednji raziskovalni pojem uveljavil kot posledica postmodernističnega obrata in dekonstrukcije metabesedila, je bil $\mathrm{v}$ antropologiji glavni vzrok za raziskovalno osredotočenje na spomin fenomenološki obrat, ki je privedel do obravnavanja telesa kot prostora spomina ter povezovanja spomina $s$ kraji in predmeti (Berliner, 2005, 200-201).

Številne študije, ki na tak ali drugačen način obravnavajo spomin, ter priročne skovanke - med njimi so najpogostejše spominski boom, spominski oziroma mnemonični obrat in spominska industrija - , $s$ katerimi skušajo posamezni teoretiki opredeliti konceptualni premik na obravnavanih dveh raziskovalnih področjih, vzbujajo vtis, da je do njega v resnici prišlo. Vendar pa, podobno kot David Berliner, tudi Ene Kõresaar izpostavlja, da je jasno zgolj to, da do obrata, če se je sploh zgodil, ni prišlo $\mathrm{v}$ obeh disciplinah sočasno, sprememba $\mathrm{v}$ njiju ni potekala po istih trajektorijah, pa tudi koncepti, razviti za označevanje posameznih mnemoničnih praks, še zdaleč niso enotni (Kõresaar, 2014, 8). To ne velja zgolj na ravni primerjave zgodovinopisja in antropologije, pač pa tudi za vsako področje posebej. Kot sta poudarila Jay Winter in Emmanuel Sivan, pogostost in lahkotnost uporabe izrazov spomin in kolektivni spomin dajeta popolnoma napačen občutek, da o njunem pomenu in načinu, kako ju uspešno uporabljati v okviru zgodovinske študije, med posameznimi raziskovalci obstaja konsenz (Winter, Sivan, Introduction, 2000, 1). Podobno velja za antropološke študije. 
Ob splošnem problemu uporabe pojma spomin, ki ima pomembne implikacije za obe področji, kritiki posebej izpostavljajo tudi šibke točke nereflektirane uporabe izraza, kot se odražajo v okviru vsakega posebej. Splošni problem je v grobem zarisal že Amos Funkenstein, ki je opozoril, da je spominjanje duševno dejanje ter kot tako absolutno in popolnoma osebno. Zaradi tega je treba izraz kolektivni spomin po njegovem mnenju uporabljati v okviru jasno začrtanega pomenskega polja (Funkenstein, 1989, 5-6). Poskusi, da bi ustrezno premostili ta razkorak med mnemonično dejavnostjo posameznika, ki je edini zmožen osebnega priklica, in skupnosti, v kateri lahko poteka kvečjemu dogovorno skupno komemoriranje, segajo od zmanjševanja razlik med njima s sklicevanjem na dejstvo, da je spomin vedno, tako na individualni kot kolektivni ravni, odvisen od družbe (cf. Jerše, 2017, 249), na kar je opozoril že Maurice Halbwachs, oziroma s poudarjanjem, da se tudi na ravni kolektivnega spomina še vedno spominja posameznik (Crane, 1997, 13811385), do skrbno argumentiranih konceptualizacij, kot je shema povezave med spominom in identiteto, ki se udejanja na treh ločenih ravneh, notranji, družbeni in kulturni, Jana Assmanna (2008, 109-110). Kljub temu nekateri kritiki opozarjajo, da je kolektivni spomin še vedno neustrezno konceptualiziran kot v svojem bistvu različen od individualnega (Kansteiner, 2002, 180, 185), oziroma opozarjajo, da je posledično sporna celo uporaba izraza spominjanje za označevanje skupnostnega dejanja komemoracije (Berliner, 2005, 207-208).

Kar se tiče konceptualnih problemov na področju zgodovinopisja, je v središču pozornosti brez dvoma odnos med kolektivnim spominom in zgodovino. Aleida Assmann je v svoji študiji razvila idejo, da se je razumevanje tega odnosa skozi zgodovino spreminjalo ter je od prvotnega enačenja zgodovine in spomina prek njunega polariziranja prešlo $\mathrm{v}$ njuno razumevanje kot medsebojno dopolnjujočih se, vendar različnih družbenih praks (Assmann, A., 2008, 57). Kljub temu, da je bila njena ideja dovolj široko sprejeta, še vedno prihaja do njunega enačenja; Kerwin Lee Klein poudarja, da je treba v tem videti predvsem odraz historiografske krize (Klein, 2000, 145), Wulf Kansteiner pa kot vir nezadostne konceptualizacije spomina razume tudi prekrivanje na videz nasprotujočih si interesnih področij, spominjanja kot družbene akcije in zgodovine kot intelektualne dejavnosti (Kansteiner, 2002, 179-180). Zaradi tega kritiki vedno znova opozarjajo na nujnost doslednega ločevanja med kolektivnim spominom oziroma, še bolje, kolektivnim spominjanjem in zgodovinsko védnostjo (Winter, Sivan, Setting, 2000, 8; Stelian, 2013, 279 in sl.). Vzrok in hkrati posledica nerazločevanja med kolektivnim spominom in zgodovino je še ena pomanjkljivost spominskih študij v okviru zgodovinopisja - zanemarjanje problema recepcije kolektivnega spomina (Confino, 1997, 1394 in sl.; Kansteiner, 2002, 180). To Alon Confino vidi kot posledico političnega redukcionizma in funkcionalizma kolektivnega spomina (Confino, 1997, 1394-1395). 
Po drugi strani David Berliner poudarja, da se historiografska analiza razmaha zanimanja za spomin v antropologiji še ni vzpostavila (Berliner, 2005, 198). Kot vir potencialnih težav izpostavlja semantično multidimenzionalnost pojma spomin; ta zaznamuje spominjanje preteklih dogodkov in izkušenj kot družbeno dejavnost, hkrati pa tudi "preteklost «, ki se na ta način ohranja in prenaša, torej je spomin nekakšno kulturno skladišče (Berliner, 2005, 200-201). Za razliko od zgodovinopisja $\mathrm{v}$ antropologiji po njegovem mnenju edini razlog za razmah spominskih študij ni bil zgolj postmodernistični obrat, temveč ga je mogoče povezati tudi z razvojem same discipline oziroma enega njenih jedrnih konceptov - kontinuitete in reprodukcije družbe. Problem, ki ga pri tem posebej izpostavlja, je, da je spomin sčasoma postal krovni pojem za vse, kar se prenaša iz generacije v generacijo, za vse torej, kar je shranjeno v kulturi (Berliner, 2005, 203). Posledično prihaja do nejasnosti, saj z istim pojmom označujemo tako idejo kulture kot tudi njeno reprodukcijo. Zato poziva $\mathrm{k}$ potrebnemu terminološkemu razlikovanju (Berliner, 2005, 206). Hkrati pa Ene Kõresaar izpostavlja tiste kritike, ki kljub navdušenemu odzivu na razmah spominskih študij v antropologiji opozarjajo na vprašanje zmožnosti pojma spomin, da nadomesti $\mathrm{v}$ disciplini ustaljene koncepte. Eden od njih je prav tradicija kot osrednji antropološki koncept za označevanje kulturne kontinuitete (Kõresaar, 2014, 15).

Kljub opisanim razlikam $\mathrm{v}$ vzrokih za pojav in kasnejših smereh razvoja spominskih študij ter konceptualnim pastem uporabe pojma spomin namesto tradicionalno ustaljenih konceptov $\mathrm{v}$ okviru obeh obravnavanih raziskovalnih področij med njima vendarle obstajajo presečna polja, med drugim nekaj pomembnih raziskovalnih tem. Med njimi sta verjetno najbolj izpostavljeni odnos med kolektivnim spominom in kulturno identiteto ter razmerje med kolektivnim spominom in zgodovino oziroma dediščino. Zanimanje za spomin najrazličnejših skupnosti v okviru obeh področij je nujno vzpodbudilo tudi raziskovanje spomina posameznika. Pri tem v ospredju zanimanja ni nujno samo odnos med kolektivnim in individualnim spominom, pač pa tudi spomin kot psihološki pojav ter spominjanje kot praksa, ki ima številne funkcije tako na individualni kot kolektivni ravni. Ta tri področja so izpostavljena tudi v pričujoči tematski številki revije Ars \& Humanitas, posvečeni spominu. Avtorji prispevkov, zbranih v njej, k spominu pristopajo kot k fenomenu, ki je skupen posameznikom in skupinam. Zanima jih kot proces mišljenja, umeščen v sedanjosti, ki pa hkrati bogati preteklost z izkušnjami in oblikuje prihodnost. Posebne pozornosti so deležni najrazličnejši artefakti, tako predmeti kot kraji, ki služijo kot vzpodbujevalci spominjanja na individualni ali kolektivni ravni. Preteklost, katere podobo naj bi pomagali vzpostavljati, je vezana na različne udeležence, od posameznikov, družin in strokovne skupnosti do nacije, kar se odraža v zbranih prispevkih. 
Prispevek Simone Petru obravnava problem epizodičnega spomina. Ta oblika spomina, ki na eni strani omogoča mentalno vračanje $\mathrm{v}$ preteklost, na drugi pa načrtovanje prihodnosti, se je najverjetneje razvila samo pri človeški vrsti, pa še pri tej sorazmerno pozno - šele s pojavom modernega človeka. Namige na pojav te vrste spomina arheologi iščejo v ohranjenih arheoloških virih, med drugim v nakitu, umetnosti in nedvoumnih sledovih prakse namernega pokopavanja pokojnika, ki odražajo željo po transcendenci časa oziroma prenosu spomina (informacij) iz sedanjosti v prihodnost. Prav pojav epizodičnega spomina pa je lahko razlog za razvoj kompleksnega jezika.

Primož Vitez v svojem prispevku prinaša nov pogled na sicer uveljavljene koncepte jezikovnega znanja oziroma jezikovne zmožnosti, pri čemer izhaja iz dejstva, da je spomin predpogoj, izhodiščna mentalna dimenzija, za razvoj kakršnekoli sporazumevalne strategije. Posebno pozornost nameni učenju besedila v najrazličnejših kontekstih, šolskem, profesionalnem, religioznem. Ker besedilna kompetenca deluje po načelu stabilnosti, enako kot struktura jezikovne zmožnosti, je govorcu v jezikovni rabi pomembno, da je celota usvojenega jezika in tekstov, nastalih iz njega, stanovitna. Posebej zanimiv je avtorjev razmislek o ustaljenih jezikovnih vzorcih, verskih obrazcih oziroma molitvah, ki jih razume kot nekakšno kolektivno jezikovno zmožnost.

Tudi naslednji prispevek obravnava problem spomina v povezavi z jezikom. V njem Barbara Pihler Ciglič govori o možnostih eksplicitnih in implicitnih pomenov pri izražanju odnosa do časa in spomina v poeziji španskega pesnika srebrne dobe Juana Ramóna Jiméneza, natančneje, pesmih, zbranih v dveh njegovih zbirkah, Eternidades (1918) in Piedra y Cielo (1919). Avtorica izhaja iz ugotovitve, da je umeščenost v čas značilna za kakršnokoli dejanje sporočanja, torej jo je treba upoštevati tudi pri analiziranju pesniškega jezika. V središču njene pozornosti so postopki izražanja časovne dimenzije s pomočjo španskih glagolskih paradigem, ki priklicujejo časovni vidik spomina in pozabe.

Prispevek Sabine Buchwald na primeru zbirke ohranjenih osebnih pisem vojaka $\mathrm{v}$ drugi svetovni vojni v navezavi $\mathrm{z}$ njegovim dnevnikom in nekaj desetletij po koncu vojne zapisanimi spomini obravnava razmerje med individualnim in kolektivnim spominom. Sistematično, s pomočjo tematiziranja pisem kot zgodovinskega vira, časovne in prostorske razsežnosti zgodovine, ujete $\mathrm{v}$ spominih, problema mentalitet oziroma identitet ter odnosa med literaturo in kulturnim spominom, prikaže njihovo medbesedilnost. Glede na to, da je bil avtor pisem koroški Slovenec, je poseben poudarek namenjen izseljevanju koroških Slovencev kot poskusu brisanja kulturnega spomina. Prispevek prikaže kompleksnost problematike uporabe 
pisem kot virov za razumevanje kolektivnega spomina, še posebej v tako izrednih okoliščinah, kot je vojna.

Helena Jaklitsch v svojem prispevku obravnava problematiko t. i. izbrisanega kolektivnega spomina na primeru Kočevarjev. Ponuja razmislek o zavestno pozabljeni skupnosti, ki je, čeprav ne prepoznana kot taka, izrednega pomena za razumevanje zgodovine našega ozemlja. Pri tem pokaže, da so proces pozabljanja sicer narekovali zunanji pritiski, vendar pa tudi bolj ali manj zavestne odločitve pripadnikov skupnosti, ki so jih sprejemali kot odziv na zunanje pritiske. Odpoved lastni tradiciji in jeziku, pospešeno odseljevanje $\mathrm{v}$ tujino hkrati $\mathrm{z}$ uničenjem praktično vseh materialnih artefaktov kočevarske kulture - vse to je na koncu pripeljalo do tega, da je ta kultura utonila v pozabo.

Mojca Smolej obravnava razvoj na področju slovenskih slovnic, pri čemer posebej izpostavi razliko pred in po sredini 19. stoletja. Pri svoji analizi izhaja iz teorije stališč do jezika. Če je bilo za zgodnejše obdobje značilno, da je bilo hkrati v uporabi več metodološko različnih slovnic, ki so se teoretsko in didaktično dopolnjevale, je za mlajše obdobje značilna veljavnost ene same, "pravilne« slovnice. Tako razumevanje, čeprav deloma pogojeno s prakso sodobne, kot skupinski dosežek razumljene gramatikografije, je značilno še danes in deloma ovira razvoj slovničarstva na Slovenskem. Pri tem je, kot izpostavi avtorica, toliko bolj zanimivo nespominjanje zgodnjega obdobja, zaznamovanega s pluralnostjo in svobodo.

Prispevek Zale Pavšič obravnava problematiko pozabljanja kot pomembnega dela t. i. spominskih študij. Kot študijski primer služi družabna namizna igra Monopoly, natančneje, njena verzija, prirejena za uporabo v nekdanji Jugoslaviji, iz 80. let prejšnjega stoletja. Tematsko je bila prilagojena za uporabo v Jugoslaviji, saj so igralna polja predstavljala geografske lokacije s celotnega ozemlja nekdanje skupne države. Z njenim razpadom oziroma razpadom njenih državljanov kot ene skupnosti je začel kopneti tudi njen kolektivni spomin, vzpostavljati pa so se začeli novi kolektivni spomini, vezani na nove, manjše skupnosti. Na podlagi izvedenih intervjujev avtorica na mikroravni posameznika prikaže razkorak med spominom intervjuvancev in spominom, kakor je materializiran v obravnavani družabni igri.

Luka Ručigaj, Monika Deželak Trojar, Anja Dular in Sonja Svoljšak v svojem prispevku predstavljajo najnovejša spoznanja o eni najpomembnejših plemiških knjižnic na našem ozemlju, Knežji Auerspergovi fidejkomisni knjižnici. Prispevek pa ne ponuja zgolj odgovorov na vprašanja, ki se nanašajo na ureditev knjižnice v nekdanji mestni palači in na njeno strukturno razdelitev, marveč jo umešča tudi $\mathrm{v}$ širši kontekst zgodovine plemiških zbirk kot svojevrstne oblike ohranjanja spomina. Ker so bile tovrstne zbirke pogosto neposredno odvisne od osebne zavzetosti in 
miselnih obzorij posameznega lastnika ali posamezne generacije zbirateljev, pokaže tudi na njeno izpovednost kot arhiva kot takega.

Prispevek Chikako Shigemori Bučar obravnava najstarejše japonske razglednice v Sloveniji. Stare razglednice so pomemben del širše kategorije virov, t. i. nepisnih virov, katerih preučevanje se je v zadnjih desetletjih uveljavilo v okviru raziskovanja zgodnjih kulturnih stikov med Daljnim vzhodom in Evropo. Najstarejše ohranjene japonske razglednice na Slovenskem so iz obdobja med letoma 1899 in 1923. Prispevek prinaša pomembne nove ugotovitve, vezane na 7 najstarejših med njimi, ki jih je leta 1899 do sedaj neznani avtor poslal domov na Kranjsko. Kot pokaže avtorica, je šlo za Jožefa Obereignerja, sina upravnika snežniškega gospostva, ki je bil strojni inženir v avstroogrski vojni mornarici.

Mojca Ilc Klun v svojem prispevku predstavlja poskus, kako v okviru učnega gradiva življenjske zgodbe in spomine posameznikov, ki so se iz Slovenije izselili sami oziroma so se iz Slovenije v Združene države Amerike, Kanado in Avstralijo izselili že njihovi predniki, uporabiti za predstavitev fenomena slovenskega izseljenstva. Kot pokaže, kombinacija zgodb, ki šolarjem in dijakom namesto zgolj naštevanja golih dejstev ponujajo predstavitev čustev, resničnih izkušenj in spominov migrantov, ter spremljevalnih pojasnil, ki posamezne zgodbe vpenjajo v širši družbeno-zgodovinski kontekst, omogoča boljše razumevanje fenomena izseljevanja na lokalni oziroma regionalni ravni ter uvid v globalne migracijske procese.

Polona Petek in Petra Roter $\mathrm{v}$ svojem prispevku predstavljata problem konfliktnega odnosa med ustvarjalno svobodo ter vlogo spominjanja $\mathrm{v}$ procesu oblikovanja in krepitve ideje nacije oziroma nacionalne države. Avtorici z razširitvijo ustaljenega družboslovnega pristopa k obravnavi filma, ki izhaja predvsem iz njegove estetske in ideološke interpretacije, na transnacionalno raven, ki vključuje tudi analizo distribucijskih, institucionalnih in drugih vidikov, obravnavata film Matilda ruskega režiserja Alekseja Jefimoviča Učitelja. Na podlagi analize javnega zgražanja, še preden je bil film sploh prvič prikazan na platnih, pokažeta na vlogo spominjanja kot dominantne kolektivne percepcije $\mathrm{v}$ okviru vnovičnega vzpostavljanja ruske nacionalne identitete kot spoja ruskega jezika, pravoslavne cerkve in ruske etnične identitete.

V svojem prispevku na podlagi analize treh besedil, ki jih je Josip Mantuani objavil $\mathrm{v}$ času vzpostavljanja modernega institucionaliziranega varstva tega, kar danes $\mathrm{s}$ skupnim pojmom imenujemo kulturna dediščina, na Slovenskem, analiziram njegovo razumevanje medsebojnega razmerja med spomeniškim varstvom in domovinskim varstvom. Na podlagi skrbne primerjave vseh treh besedil se namreč jasno začrta razlika, ki jo je Mantuani razumel med spomeniki, ki so bili s svojim značajem, obliko 
in vsebino še usidrani v obstoječo tradicijo, in tistimi, ki jih je razumel le še kot »neme priče " preteklih kultur, $\mathrm{z}$ drugimi besedami, kot zgodovinske vire. Prvim je pripisoval »živo kulturno« vlogo, druge je razumel kot »arhivsko gradivo«.

Robert Jereb na primeru Idrije obravnava povezavo med habitusom, strukturiranim odnosom do stvarnosti določene lokalne skupnosti ter njegovo odvisnostjo od kolektivnega spomina. Ker ima ta vedno tudi prostorsko razsežnost, avtor njegove elemente išče tako $\mathrm{v}$ stvarnem urbanem okolju Idrije kot tudi v imaginariju tega prostora, torej v naboru podob, v katerih se odraža razumevanje identitete Idrijčanov kot skupnosti, vezane na konkretno okolje, v katerem živijo. Glede na to, da je Idrija mesto, ki je s svojim nastankom in razcvetom vezano na rudnik, ni presenetljivo, da so med njimi posebej pomembni objekti tehniške dediščine. Po drugi strani pomembno vlogo igra tudi lokalna stavbna dediščina. Posebno pozornost avtor namenja identifikaciji prostorov spomina $\mathrm{v}$ današnji Idriji.

Prispevek Mateje Kos prinaša tehten pretres strokovnih in znanstvenih stališč o muzejih kot ustanovah, katerih naloga je ohranjanje kolektivnega spomina, in njihovih konceptih ravnanja $\mathrm{z}$ njim. Posebna pozornost je namenjena nacionalnim muzejem, katerih poslanstvo je osredotočeno na posebno obliko kolektivnega spomina - nacionalni spomin -, kar odpira eno najpomembnejših vprašanj, vezano na njihovo delovanje, vprašanje njihove narodotvornosti. Kot taki so nacionalni muzeji ustanove, ki so zaradi narave svojega dela na začetku 21. stoletja še posebej na udaru zaradi ustaljenih načinov delovanja. Med največjimi izzivi, s katerimi se soočajo, so poleg prenosa pozornosti z nacionalnega na regionalni in celo lokalni kolektivni spomin vse glasnejše zahteve po inkluzivnosti in participatornosti.

Neža Čebron Lipovec obravnava problematiko kolektivnega spomina in dediščine, natančneje, njun medsebojni odnos na t. i. spornih ozemljih, torej ozemljih, ki si jih lasti več skupnosti z različnimi kolektivnimi spomini. Kot primer služijo mesta slovenske Istre po drugi svetovni vojni. Avtorica obravnava napetosti med kolektivnimi spomini v času, ko je na tem ozemlju zaradi političnih in družbenih sprememb po koncu vojne prišlo do velikih socialnih in etničnih premen, kot se kažejo v urbanem okolju. V središče analize postavi enega od javnih spomenikov, doprsni kip koprskega protestantskega škofa Pier Paola Vergerija mlajšega. Na njegovem primeru pokaže, kako so javni spomeniki prav zaradi svoje funkcije reprezentacije položaja moči na eni ter umeščenosti $\mathrm{v}$ javni prostor na drugi strani idealni poligon za preučevanje medsebojne povezave med skupnostno identiteto, ozemljem in preteklostjo, kot se kaže skozi kolektivni spomin. 
Simona Žvanut v svojem prispevku predstavlja projekt Art House Project na japonskem otoku Naoshima, v okviru katerega so umetniki v sodelovanju $\mathrm{z}$ arhitekti stare japonske hiše $\mathrm{v}$ vasi Honmura predelali v umetniška dela. Hiše stojijo na različnih lokacijah, $v$ proces njihove predelave pa je občasno vključena tudi lokalna skupnost. Gre za zelo kompleksen projekt, saj na različnih ravneh prepleta sodobno umetnost in arhitekturo, restavracijo stare arhitekture in kontekst otoške vasi. Hkrati avtorji projekt jasno povezujejo s kolektivnim spominom. Avtorica na podlagi skrbne analize izbranih hiš in ob uporabi temeljnih konceptov (spomin, zgodovina, kolektivni spomin) opozori na trenutno precej problematično rabo tega pojma $\mathrm{v}$ zvezi s projektom. Hkrati nakaže možnosti, kako bi v okviru tega revitalizacijskega projekta vendarle lahko izpostavili tudi kolektivni spomin.

\section{Bibliografija}

Assmann, A., Transformations between History and Memory, Social Research 75/1, 2008, str. 49-72.

Assmann, J., Collective Memory and Cultural Identity, New German Critique 65, 1995, str. $125-133$.

Assmann, J., Communicative and Cultural Memory, v: Cultural Memory Studies. An Introduction and Interdisciplinary Handbook (ur. Erill, A., Nünning, A.), Berlin, New York 2008, str. 109-118.

Berliner, D., The Abuses of Memory: Reflections on the Memory Boom in Anthropology, Anthropological Quarterly 78/1, 2005, str. 197-211.

Confino, A., Collective Memory and Cultural History: Problems of Method, The American Historical Review 102/5, 1997, str. 1386-1403.

Crane, S. A., Writing the Individual Back in Collective Memory, The American Historical Review 102/5, 1997, str. 1372-1385.

Funkenstein, A., Collective Memory and Historical Consciousness, History and Memory 1/1, 1989, str. 5-26.

Jerše, S., Slovenski kraji spomina. Pojmi, teze in perspektive zgodovinskih raziskav, Zgodovinski časopis 71/1-2, 2017, str. 246-267.

Kansteiner, W., Finding meaning in memory: a methodological critique of collective memory studies, History and Theory 41, 2002, str. 179-197.

Klein, K. L., On the Emergence of Memory in Historical Discourse, Representations 69, 2000, str. 127-150.

Kõresaar, E., Concepts around selected pasts: on "mnemonic turn" in cultural research, Folklore. Electronic Journal of Folklore 57, 2014, str. 7-28. 
Stelian, M., History and Collective Memory: the Succeeding Incarnations of an Evolving Relationship, Philobiblon XVIII/2, 2013, str. 260-282.

Winter, J., Sivan, E., Introduction, v: War and Remembrance (ur. Winter, J., Sivan, E.), Cambridge 2000, str. 1-5.

Winter, J., Sivan, E., Setting the framework, v: War and Remembrance (ur. Winter, J., Sivan, E.), Cambridge 2000, str. 6-39. 